\title{
A Taxonomic Study of the Aeromonas hydrophila-Aeromonas punctata Group
}

\author{
By M. POPOFF \\ Service des Entérobactéries, Institut Pasteur, 75015 Paris, France \\ AND M. VERON \\ Laboratoire de Bactériologie, Faculté de Médecine Necker, Paris
}

(Received 3 March 1975; revised 30 September 1975)

\begin{abstract}
SUMMARY
A total of 203 characters has been determined for 68 strains of Aeromonas belonging to the Aeromonas hydrophila-A. punctata group. The results have been subjected to computer analysis using the coefficient of Jaccard-Sneath and the strains clustered by the method of aggregation according to the variance.

The 68 strains can be divided into two well-segregated classes on the basis of 59 variable characters, of which seven are of diagnostic value. The two classes are considered as two separate species. The first one ( 42 strains) is assigned to the type species of the genus, $A$. hydrophila, and it appears that the species name, $A$.punctata, is an illegitimate synonym for $A$. hydrophila. The second (26 strains) constitutes a new species for which the name $A$. sobria sp.nov. is proposed. The type strain of this new species has been deposited under the reference CIP7433 (our strain 208).
\end{abstract}

\section{INTRODUCTION}

The genus Aeromonas was proposed by Kluyver \& van Niel (I936) to accommodate rodshaped bacteria possessing the general properties of the enteric group, but motile by means of polar flagella. This genus is now included in the family of Vibrionaceae (Véron, 1966). In Bergey's Manual of Determinative Bacteriology (1974) the original definition has been amended to include the following salient properties: Gram-negative straight rods; polar flagellated (generally monotrichous) or immotile; facultative anaerobes, fermenting carbohydrates with formation of acid or acid and gas; oxidase positive; reducing nitrates to nitrites; insensitive to the vibriostatic compound 2,4-diamino-6,7-diisopropylpteridine (O/I29); guanine-cytosine content of the DNA, 57 to $63 \mathrm{~mol} \%$.

Of the three species now recognized (Bergey's Manual of Determinative Bacteriology, 1974), the fish pathogen Aeromonas salmonicida is easily distinguishable by the following characters: non-motile; auxotrophy; no growth at $37^{\circ} \mathrm{C}$; producing a brown diffusible pigment on nutrient agar; indole not formed. Smith (1963) has even suggested removing this species from the genus Aeromonas, proposing the alternative name Necromonas salmonicida. The ' $A$. hydrophila-A. punctata' group is more complex; Schubert (1967a, $b, 1968)$ proposed a total of five sub-species, three assigned to $A$. hydrophila and two to $A$. punctata. Our attempts to classify newly-isolated strains of the hydrophila-punctata complex in terms of the specific and sub-specific criteria proposed by Schubert have indicated that this scheme is unsatisfactory. The present study attempts to clarify and simplify the classification of aeromonads not assignable to the species $A$. salmonicida. 
Table I. Proposed taxonomic classification of the new isolates

\begin{tabular}{lll}
$\begin{array}{c}\text { Assigned to } \\
\text { Aeromonas hydrophila }\end{array}$ & Source & \multicolumn{1}{c}{ Strain nos. } \\
(class X) & Man & $102,230,231,241,246,247,268,307,308$ \\
& Fish & $201,203,212,213,214,216,218,219,222,223,225,226$, \\
& Frog & $247,229,233,234,235,238,239$ \\
& Fresh water & 244 \\
A. sobria sp.nov. & Man & 243 \\
(class Y) & Fish & $202,204,205,207,208,209,210,211,215,217,221,224$, \\
& & $228,232,236,237,240,242$
\end{tabular}

\section{METHODS}

Origin of the strains. In addition to 16 named strains, a detailed study of 52 wild-type strains possessing the properties of the hydrophila-punctata complex was made. They were isolated between 1967 and 1974 from the following sources: human pathological specimens submitted to bacteriological examination (Io strains); infected fishes ( 37 strains); infected frogs (4 strains); fresh water (I strain). In Table $\mathrm{I}$, the new isolates are listed in terms of the taxonomic classifications now proposed as a result of our analysis. The origins and assignments of the 16 named strains are listed in Table 2.

Properties examined. In addition to the basic characters quoted in the Aeromonas group definition (see above), we examined a total of 57 characters previously used in taxonomic studies of the Aeromonas group or which are standard procedures for the identification of the enteric group of bacteria. They are listed below; those for which no reference is given are described by Popoff (1969):

Morphological characters: capsule; motility.

Physiological characters: catalase production; growth in $\mathrm{KCN}$ medium; methyl red and Voges-Proskauer reactions; maximum temperature for growth in nutrient broth $(30,37$ and $4 \mathrm{I}{ }^{\circ} \mathrm{C}$ ); growth factor requirements using a mineral-ammonium medium containing glucose or succinate as sole source of carbon and energy; growth in peptone water in the presence or absence of sodium chloride (Richard, Giammanco \& Popoff, 1974).

Carbohydrate metabolism: production of acid and gas from glucose and glycerol; production of acid from L-arabinose, D-xylose, L-rhamnose, D-mannose, sorbose, D-cellobiose, D-lactose, D-maltose, melibiose, D-sucrose, D-trehalose, raffinose, erythritol, adonitol, D-mannitol, D-dulcitol, mesoinositol, D-sorbitol, mucate, salicin; esculin hydrolysis; production of $\beta$-galactosidase and butanediol-dehydrogenase (Schubert \& Kexel, 1964).

Metabolism of nitrogenous compounds: production of urease, lysine decarboxylase, ornithine decarboxylase, arginine dihydrolase, tryptophan deaminase, phenylalanine deaminase, tetrathionate reductase; indole production in peptone water; $\mathrm{H}_{2} \mathrm{~S}$ production on Kligler's medium and from cysteine on cysteine-iron agar (Gélose G.C.F.; Véron \& Gasser, 1963).

Extracellular enzymes: production of gelatinase, elastase (Scharmann, 1972), pectinase (Davis \& Ewing, 1964), lipase, DNAase and RNAase.

All cultures were incubated at $30{ }^{\circ} \mathrm{C}$; the reactions were observed for 2 days for growth in $\mathrm{KCN}$ medium and for $\mathrm{I}$ to 4 days for the other tests.

In addition, strains were screened for their ability to use as principal sources of carbon and energy, the 146 organic compounds studied by Stanier, Palleroni \& Doudoroff (I966), using the media and techniques described by Véron (I975). The mineral-ammonium medium 
Table 2. The sources and assignations of the 16 named strains

Strain no.*
Strainsassigned to $A$. hydrophila
267 (NCIB9234 = ATCC13136)
309 (CIP R307)
314 (Lille CIO5), 315 (Lille
CI06), 316 (Lille CI02)
317 (Lille C94), 318 (Lille
C95), 319 (Lille C98)
543 (ATCC7966 =
NCTC8049 = NCMB86 =
NCIB9240 = CDC-RH35)
544 (ATCCI 5467)
545 (ATCCI5468)
546 (NCMB74 = ATCC23309
S Schäperclaus strain B =
CDC-RH63)

Received as

Source

Strains assigned to A. hydrophila (class X)

A. formicans

A. punctata

A. dourgesi var. aerogenes

Oil emulsion (Pivnick \& Sabina, 1957)

Man (Delabre et al., 1973)

A. dourgesi var. anaerogenes

A. hydrophila subsp. hydrophila, neotype strain

Fresh water (Leclerc, 1962)

A. hydrophila subsp. anaerogenes, type strain

A. punctata subsp. caviae, type strain

Fresh water (Leclerc, 1962)

A. punctata subsp. punctata,

Canned milk (Speck \& Stark, 1942)

neotype strain

Strains assigned to $A$. sobria (class $\mathrm{Y}$ )
$310($ CIP6324 $=$ CCEB36)
A. punctata
Unknown source (Lysenko, 196I)
31 I $($ CIP5749 $=$ NCTC7810
$=$ ATCC907I)
A. hydrophila
Frog (Kulp \& Borden, 1942)
320 (Lille Cr03)
A. dourgesi var. anaerogenes
Fresh water (Leclerc, 1962)

Strain excluded from the genus Aeromonas
262 (NCMBI $326=$ ATCC I5338)
A. proteolytica, type strain $\quad$ Marine crustacea (Merkel et al., 1964)

* NCMB, National Collection of Marine Bacteria, Aberdeen; ATCC. American Type Culture Collection, Rockville, Maryland, U.S.A.; NCIB, National Collection of Industrial Bacteria, Aberdeen; CIP, Collection of the Institut Pasteur, Paris, France; CCEB, Culture Collection of Entomogenous Bacteria, Praha, Czechoslovakia; Lille, Collection of Professor H. Leclerc, Lille, France.

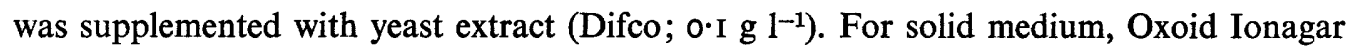
no. 2 was used (I \%,w/v). The growth on the plates was read around each substrate spot after 3 and 5 days at $30^{\circ} \mathrm{C}$.

Numerical taxonomy. A total of 203 simple, qualitative characters was codified in binary form. The coefficient $D$ used for taxonomic distance was given by $D=\mathrm{I}-S, S$ being the similarity coefficient of Jaccard-Sneath (Sokal \& Sneath, 1963). Strains clusters were set up by the method of aggregation according to the variance (Delabre, Bianchi \& Véron, 1973). Classes were delimited by computing the coefficient of distinctness (previously termed 'acuteness coefficient'; Véron, 1974). The diagnostic value of the characters was determined by the method of Gyllenberg (1965). The characters of greatest differential value were selected to define ideal phenotypes (Stanier et al., 1966). The centrotype of a taxon was defined as the strain of minimum average distance among the strains of this taxon (Silvestri et al., 1962).

Programmes and computations were made on a Wang 2200 computer.

DNA base compositions. The mole per cent guanine plus cytosine ( $\mathrm{mol} \% \mathrm{GC}$ ) in the DNAs of representative strains was determined by the method of Marmur \& Doty (1962). The thermal denaturation profiles were determined in $0.1 \times$ SSC (standard saline citrate: 
$0.15 \mathrm{M}-\mathrm{NaCl}, 0.015 \mathrm{M}$-sodium citrate) at $\mathrm{pH} 7.0$, on a Gilford 240 spectrophotometer fitted with a temperature programmer. The mol \% GC was calculated by the method of De Ley (1970) using Escherichia coli KI 2 (CIP54I I7) as the standard.

\section{RES ULTS}

\section{Characters either positive or negative for all strains examined}

A total of 28 characters, positive for all strains, included: the ability to ferment mannitol, maltose and trehalose; the production of catalase, DNAase, RNAase, gelatinase, lipase and arginine dihydrolase; the utilization, as principal carbon and energy sources, of 19 substrates, namely D-ribose, D-fructose, D-galactose, D-glucose, D-maltose, D-trehalose, D-gluconate, starch, caprylate, pelargonate, caprate, succinate, fumarate, DL-glycerate, L-malate, glycerol, D-mannitol, L-aspartate, L-glutamate.

Characters negative for all strains were: capsule; pectinase, lysine and ornithine decarboxylases; tryptophan and phenylalanine deaminases; fermentation of xylose, sorbose, erythritol, adonitol, dulcitol, inositol and mucate; production of $\mathrm{H}_{2} \mathrm{~S}$ on Kligler medium. In addition, 95 of the substrates tested as principal sources of carbon and energy were never utilized. These can be ascertained from the list of substrates given by Stanier et al. (1966), but eliminating the 19 utilized by all our strains as well as certain others used by some of the strains examined (quoted in Tables 3, 4 and 6).

\section{Numerical analysis}

Among the 64 variable characters, it appeared that fermentation of L-arabinose, L-rhamnose, D-sucrose and D-lactose was redundant with utilization of these four substrates as principal energy sources; in addition, growth on $\mathrm{D}-\alpha$-alanine was also redundant with $\mathrm{L}-\alpha$-alanine. Consequently these five characters were omitted from numerical analyses, which were finally performed with 59 characters (see Tables 3 to 6).

Figure I shows the similarity relationships between the 68 strains examined. A primary division of these strains into two groups is obvious. The highest values of the coefficient of distinctness $K$, for the hierarchic levels $H$, are: $K=36.52$ for $H=0.15 ; K=38.08$ for $H=0.24$; and $K=\mathrm{I} 3 \mathrm{I} \cdot 28$ for $H=0.99$.

The best cutting level for the dendrogram is therefore at $H_{\text {opt }}=0.99$. At this level, there are two well separated primary classes, $X$ and $Y$, containing 42 and 26 strains respectively. The strains in each class are shown in Fig. I.

The coefficients of distinctness within each primary class $\left(K_{\mathrm{X}}\right.$ and $\left.K_{\mathrm{Y}}\right)$ were calculated for every hierarchic level less than or equal to $H_{\text {opt }}$. The value of the coefficient $K$ within both classes is maximal for the level $H=0.99$. Within each class, the two highest values of the coefficient $K$ occurred at the following levels: $K_{\mathrm{x}}=6 \mathrm{I} \cdot 95$ for $H=0.99$ and $K_{\mathrm{X}}=24.4 \mathrm{I}$ for $H=0.39$ in class $\mathrm{X}$; and $K_{\mathrm{Y}}=69.33$ for $H=0.99$ and $K_{\mathrm{Y}}=27.42$ for $H=0.24$ in class $\mathrm{Y}$. The ratios of the two $K$ values are 0.40 and 0.39 , respectively, for $\mathrm{X}$ and $\mathrm{Y}$. The low values of these ratios suggests that the primary classes, $\mathrm{X}$ and $\mathrm{Y}$, must not be divided into secondary classes (Véron, 1974). However, from the disposition of clusters in Fig. I, the subdivision of class $X$ into two biovars, $X_{1}$ ( 13 strains) and $X_{2}$ (29 strains), may be considered.

For the three taxa, the centrotypes are strains 2 I $8\left(\mathrm{X}_{1}\right), 239\left(\mathrm{X}_{2}\right)$ and $208(\mathrm{Y})$, which have been deposited in the Collection of the Institut Pasteur (Paris) under the numbers CIP7430, CIP7432 and CIP7433. Within their own taxa, these centrotypes show an average coefficient of similarity of $0.770\left(\mathrm{X}_{1}\right), 0.7 \mathrm{I}$ I $\left(\mathrm{X}_{2}\right)$, and $0.69 \mathrm{I}(\mathrm{Y})$. 


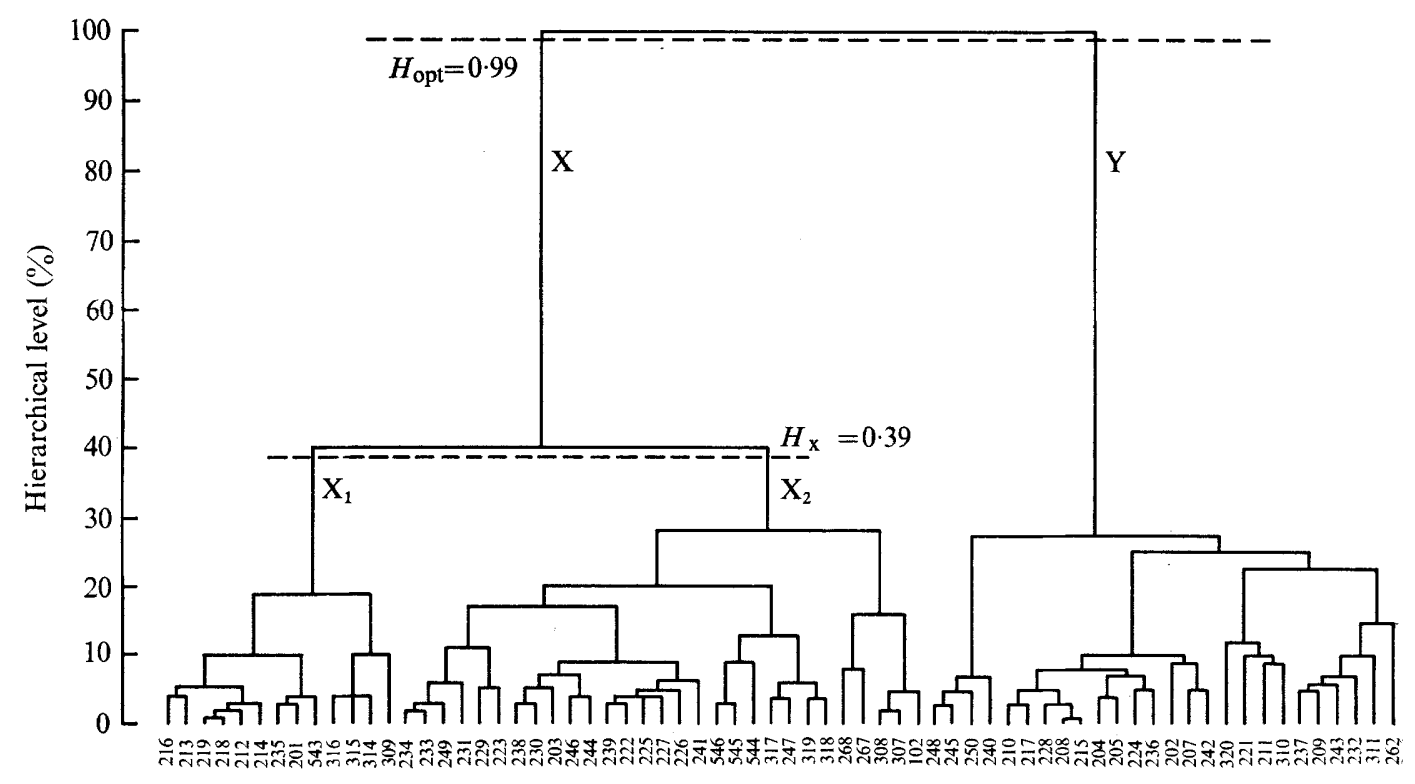

Fig. I. Numerical analysis of strains.

Table 3. Characters of value for differentiation of classes $X$ and $Y$

\begin{tabular}{|c|c|c|c|c|c|c|}
\hline \multirow{3}{*}{$\begin{array}{l}\text { Designation of the } \\
\text { characters }\end{array}$} & \multicolumn{3}{|c|}{ Class X (42 strains) } & \multicolumn{3}{|c|}{ Class Y (26 strains) } \\
\hline & \multicolumn{2}{|c|}{$\begin{array}{c}\begin{array}{c}\text { Positive } \\
\text { strains }\end{array} \\
\end{array}$} & \multirow[b]{2}{*}{ Negative strains } & \multicolumn{2}{|c|}{$\begin{array}{l}\text { Positive } \\
\text { strains }\end{array}$} & \multirow[b]{2}{*}{ Negative strains } \\
\hline & Total & $\%$ & & Total & $\%$ & \\
\hline Esculin hydrolysis & 42 & 100 & None & 5 & 19 & $\begin{array}{l}\text { All except 204, 22I, 240, } \\
310,320\end{array}$ \\
\hline Fermentation of salicin & 36 & 86 & $\begin{array}{l}201,268,307,308,543, \\
544\end{array}$ & 5 & 19 & $\begin{array}{l}\text { All except 2I I, 22I, 240, } \\
310,320\end{array}$ \\
\hline $\begin{array}{l}\mathrm{H}_{2} \mathrm{~S} \text { production in } \mathrm{GCF} \\
\text { agar* }\end{array}$ & 13 & $3 \mathrm{I}$ & $\begin{array}{l}\text { All except 20I, 2I 2, 2I 3, } \\
214,2 \text { I 6, 2 I 8, 21 } 9,229, \\
235,315,316,544,545\end{array}$ & 25 & 96 & 262 \\
\hline Growth on $\mathrm{KCN}$ medium & $4 \mathrm{I}$ & 98 & 319 & 5 & 19 & $\begin{array}{l}\text { All except 205, 209, 243, } \\
310,320\end{array}$ \\
\hline Growth on L-arabinose & 39 & 93 & 223,318 & 5 & 19 & $\begin{array}{l}\text { All except 209, 236, } 310 \text {, } \\
\text { 3I I, } 320\end{array}$ \\
\hline Growth on salicin & 33 & 79 & $\begin{array}{l}102,201,227,267,268 \\
307,308,543,544\end{array}$ & 6 & 23 & $\begin{array}{l}\text { All except } 21 \text { I, 22I, 240, } \\
250,31 \text { I , 320 }\end{array}$ \\
\hline Growth on L-arginine & $3 I$ & 74 & $\begin{array}{l}201,203,223,229,231, \\
235,268,309,314,315 \\
316\end{array}$ & 2 & 8 & All except 223, 250 \\
\hline Growth on L-histidine & 4I & 98 & 229 & 2 & 8 & All except 243,320 \\
\hline
\end{tabular}


Table 4. Characters almost always positive or negative for the 68 strains examined

Characters
Minimal concentration of $\mathrm{NaCl}$
$=0 \%$
Minimal concentration of $\mathrm{NaCl}$
$=0.5 \%$
Maximal concentration of $\mathrm{NaCl}$
$=3 \%$
Maximal concentration of $\mathrm{NaCl}$
$=10 \%$
$\beta$-Galactosidase production
Growth factors required
Fermentation of mannose
Fermentation of raffinose
Fermentation of glycerol
Fermentation of melibiose
Indole production
Growth on rhamnose
Growth on mannose
Growth on sucrose
Growth on D-sorbitol
Growth on isobutyrate
Growth on DL-3-hydroxybutyrate
Growth on D-malate
Growth on laevulinate
Growth on L-proline

\begin{tabular}{|c|c|c|c|}
\hline \multicolumn{3}{|c|}{ Positive strains } & \multirow[b]{2}{*}{ Negative strains } \\
\hline Total & $\%(X)$ & $\%(Y)$ & \\
\hline 67 & 100 & 96 & 262 \\
\hline $\mathbf{I}$ & 0 & 4 & All except 262 \\
\hline 67 & 100 & 96 & 262 \\
\hline $\mathbf{I}$ & 0 & 4 & All except 262 \\
\hline 67 & 100 & 96 & 262 \\
\hline 5 & 5 & 12 & All except 202, 21 I, 227, 230, 236 \\
\hline 62 & 88 & 96 & $230,249,267,268,309,317$ \\
\hline 2 & 0 & 8 & All except 236,320 \\
\hline $6 \mathrm{I}$ & 86 & 100 & $230,238,244,307,308,310,545$ \\
\hline 4 & 8 & 4 & All except $211,223,225,228$ \\
\hline 63 & 95 & 88 & $202,207,232,267,268$ \\
\hline 5 & 12 & 0 & All except $212,214,218,219,225$ \\
\hline 62 & 88 & 96 & $231,249,267,268,309,320$ \\
\hline 62 & 100 & 77 & $205,242,245,248,250,262$ \\
\hline 3 & 8 & 0 & All except 201, 227, 235 \\
\hline 5 & 8 & 8 & All except 202, 203, 224, 227, 239 \\
\hline I & 2 & 0 & All except 203 \\
\hline 2 & 5 & 0 & All except 216,222 \\
\hline 2 & 0 & 7 & All except 245,250 \\
\hline 6 & II & 4 & All except $203,221,226,236,245$ \\
\hline
\end{tabular}

\section{Description of the taxa}

Using the separation coefficient of Gyllenberg (I965), we determined the most significant characters for the differentiation of classes $\mathrm{X}$ and $\mathrm{Y}$.

Among the 59 variable characters used for classification, eight are significant for differentiating classes $\mathrm{X}$ and $\mathrm{Y}$ (see Table 3 ). The remainder are without differential value, either because they are positive for at least $90 \%$ or less than $10 \%$ of strains (see Table 4), or because their occurrence is not statistically significant (see Tables 5 and 6).

One character useful for differentiating classes $\mathrm{X}$ and $\mathrm{Y}$ (see footnote, Table 3 ) as well as three other variable characters without primary differential value (see footnote, Table 5) make it possible to differentiate between the two biovars of class $\mathrm{X}$.

We have been unable to confirm the value of one pair of 'classical' differential characters proposed by Schubert: gas production with glucose and with glycerol. In our tests, all but one strain gave results which were either both positive or both negative with these two carbohydrates.

Table 7 summarizes all the characters of value in differentiating between species, i.e. it gives the ideal phenotypes of these taxa. The proportion of strains possessing all or all but one of the characters of the ideal strain was as follows: $70 \%\left(\mathrm{X}_{1}\right), 76 \%\left(\mathrm{X}_{2}\right)$, and $66 \%(\mathrm{Y})$.

The halophilic character has not been included in the list of those used for discriminating between strains, because only one strain (strain 262) has this property; this strain requires at least $100 \mathrm{~mm}-\mathrm{NaCl}$ for growth in peptone water, and differs from the ideal phenotype of class $\mathrm{Y}$ in only two characters: elastase and $\mathrm{H}_{2} \mathrm{~S}$ from cysteine. 
Table 5. Variable characters without value for differentiation of classes $X$ and $Y$

\begin{tabular}{|c|c|c|c|c|}
\hline \multirow[b]{2}{*}{ Characters } & \multicolumn{3}{|c|}{ Positive strains } & \multirow[b]{2}{*}{ Negative strains } \\
\hline & Total & $\%(\mathrm{X})$ & $\%(\mathrm{Y})$ & \\
\hline Motility & 56 & (74) & (96) & $\begin{array}{l}102,246,307,308,309,314,315,316,317,318, \\
319,320\end{array}$ \\
\hline $\begin{array}{l}\text { Maximum temperature for } \\
\text { growth }=28^{\circ} \mathrm{C}\end{array}$ & $2 \mathrm{I}$ & (9) & (65) & $\begin{array}{l}\text { All except 102, 202, 204, 205, 207, 208, 210, } 21 \mathrm{I} \text {, } \\
215,217,221,224,228,236,242,262,267,268 \text {, } \\
307,310,320\end{array}$ \\
\hline $\begin{array}{l}\text { Maximum temperature for } \\
\text { growth }=37^{\circ} \mathrm{C}\end{array}$ & 47 & (90) & (34) & $\begin{array}{l}\text { I02, 202, 204, 205, 207, 208, 210, 211, 215, 21 } 7 \text {, } \\
22 \mathrm{I}, 224,228,236,242,262,267,268,307,310 \text {, } \\
320\end{array}$ \\
\hline $\begin{array}{l}\text { Gas production from } \\
\text { glucose* }\end{array}$ & 39 & (38) & (89) & $\begin{array}{l}\text { I02, 203, 21 I, 222, 225, 226, 227, 230, 23I, 232, } \\
233,237,238,239,241,244,246,249,267,268, \\
307,308,309,317,318,319,320,544,545\end{array}$ \\
\hline Gas production from glycerol & 38 & (36) & (89) & Idem +546 \\
\hline Tetrathionate reductase & $2 \mathrm{I}$ & (47) & (4) & $\begin{array}{l}\text { All except 203, 22I, 222, 225, 226, 227, 230, 231, } \\
233,238,239,24 \mathrm{I}, 244,247,267,317,318,543 \\
544,545,546\end{array}$ \\
\hline Fermentation of cellobiose & 50 & (7I) & (73) & $\begin{array}{l}209,212,213,218,219,221,230,237,243,262 \\
267,268,309,311,315,316,320,543\end{array}$ \\
\hline Fermentation of sorbitol & II & (19) & (II) & $\begin{array}{l}\text { All except 2II, 235, 24I, 246, 247, 262, 309, 310, } \\
\text { 3I4, 315, 3I6 }\end{array}$ \\
\hline Acetoin production* & 28 & (3I) & (57) & $\begin{array}{l}\text { All except 201, 202, 204, 205, 207, 208, 209, 21 I, } \\
212,213,214,215,216,217,218,219,228.235 \\
242,243,262,311,314,315,316,320,543,544\end{array}$ \\
\hline Methyl red & 53 & (76) & (8I) & $\begin{array}{l}201,204,205,209,212,214,216,218,219,235 \\
262,311,314,543,544\end{array}$ \\
\hline Urease & 7 & (I6) & (o) & All except I02, 23I, 267, 268, 307, 308, 309 \\
\hline Elastase* & 15 & (28) & (II) & $\begin{array}{l}\text { All except 20I, 212, 213, 214, 216, 218, 219, 235, } \\
262,310,314,315,316,320,543\end{array}$ \\
\hline Butanediol dehydrogenase & 48 & (55) & (96) & $\begin{array}{l}\text { I02, 203, 22I, 222, 226, 227, 229, 230, 233, 238, } \\
239,24 \mathrm{I}, 244,246,249,307,308,309,545,546\end{array}$ \\
\hline
\end{tabular}

\section{DNA base compositions}

The average value of the mol $\% \mathrm{GC}$ content in the DNA of representative strains of each class (Table 8) is $6 \mathrm{I} \cdot 5 \pm \mathrm{r} \cdot 7$. However, if we consider the five strains of class $X$ and the three of class $Y$ separately, the averages for these two classes $(62 \cdot 6 \pm 0 \cdot 4$ and $59 \cdot 6 \pm \mathrm{I} \cdot 0$, respectively) differ significantly $(P=0.00 \mathrm{I})$.

\section{DISCUSSION}

Since the description by Zimmerman (1890) of Bacillus punctatus (A. punctata) and by Sanarelli (I891) of $B$. hydrophilus fuscus ( $A$. hydrophila), a number of additional species of motile aeromonads has been proposed (summarized in Ewing, Hugh \& Johnson, 1961). Ewing et al. (I96I) recognized only three valid species, $A$. salmonicida, A. shigelloides and $A$. hydrophila, of which only $A$. hydrophila is included in the present study.

The most recent taxonomic studies on the hydrophila-punctata group, summarized in Table 9, give quite discordant results. The proposals of Schubert have been adopted in the most recent (8th) edition of Bergey's Manual of Determinative Bacteriology (1974), which lists characters used for the differentiation of these five taxa. 
Table 6. Variable nutritional characters without value for differentiation of classes $X$ and $Y$

\begin{tabular}{|c|c|c|c|c|}
\hline \multirow{2}{*}{$\begin{array}{l}\text { Ability to grow } \\
\text { on: }\end{array}$} & \multicolumn{3}{|c|}{ Positive strains } & \multirow[b]{2}{*}{ Negative strains } \\
\hline & Total & $\%(\mathrm{X})$ & $\%(\mathrm{Y})$ & \\
\hline D-Cellobiose & 46 & (71) & $(61)$ & $\begin{array}{l}207,209,211,212,213,216,218,219,221,231,232,237,243, \\
262,267,268,309,311,315,316,320,543\end{array}$ \\
\hline D-Lactose & 17 & (36) & (8) & $\begin{array}{l}\text { All except 102, 240, 244, 247, 267, 307, 308, 309, 314, 315, } 316 \text {. } \\
317,318,319,320,544,546\end{array}$ \\
\hline Acetate & 35 & (59) & (39) & $\begin{array}{l}204,205,208,209,211,212,213,214,215,216,217,221,222, \\
223,224,225,226,227,228,229,231,232,233,237,242,249, \\
262,267,268,310,315,320,544\end{array}$ \\
\hline Propionate & I 5 & (24) & (19) & $\begin{array}{l}\text { All except 102, 202, 203,230, 238, 239, 240, 24I, 244, 245, 246, } \\
248,250,317,319\end{array}$ \\
\hline Butyrate & 22 & (38) & (23) & $\begin{array}{l}\text { All except 202, 203, 222, 225, 227, 230, 238, 239, 240, 24I, 244, } \\
245,246,248,250,311,314,315,317,543,545,546\end{array}$ \\
\hline $\mathrm{n}$-Valerate & 28 & (55) & (23) & $\begin{array}{l}\text { All except 202, 203,213,214,216,218,219,222, 225, 227, 23I, } \\
232,233,234,238,239,240,241,244,245,246,248,249,250, \\
316,317,545,546\end{array}$ \\
\hline n-Caproate & 48 & (76) & $(6 \mathrm{I})$ & $\begin{array}{l}207,209,2 \mathrm{II}, 22 \mathrm{I}, 223,228,237,242,309,3 \mathrm{I} 0,3 \mathrm{II}, 3 \mathrm{I} 4,3 \mathrm{I} 5, \\
3 \mathrm{I} 8,319,320,543,544,545,546\end{array}$ \\
\hline Heptanoate & 47 & $(76)$ & $(58)$ & $\begin{array}{l}202,207,209,211,221,223,228,229,237,241,242,303,310, \\
311,318,319,320,543,544,545,546\end{array}$ \\
\hline DL-Lactate & 23 & $(45)$ & (15) & $\begin{array}{l}\text { All except 102, 21 2, 21 } 3,221,231,233,234,244,245,246,247 \\
248,249,250,267,308,309,317,318,319,543,544,545\end{array}$ \\
\hline Pyruvate & 59 & $(88)$ & (84) & $245,268,307,308,309,310,311,315,320$ \\
\hline Citrate & 48 & $(82)$ & (50) & $\begin{array}{l}202,203,204,205,207,211,221,224,227,230,235,236,240, \\
242,244,250,268,310,311,546\end{array}$ \\
\hline $\begin{array}{l}L-\alpha-A l a n i n e \\
D-\alpha-\text { Alanine }\end{array}$ & 34 & $(76)$ & (8) & $\begin{array}{l}\text { All except 102, 201, 203, 21 2, 21 3, 216, 218, 221, 222, 225, 227, } \\
231,233,234,235,239,241,244,246,247,250,268,307308, \\
309,314,315,316,317,318,319,543,545,546\end{array}$ \\
\hline L-Ornithine & 22 & (45) & (15) & $\begin{array}{l}\text { All except } 203,213,214,222,225,226,227,230,238,239,241 \text {, } \\
245,247,248,250,317,318,320,543,544,545,546\end{array}$ \\
\hline L-Serine & 53 & $(83)$ & (69) & $\begin{array}{l}102,202,210,211,217,233,234,244,262,267,307,308,310, \\
311,545\end{array}$ \\
\hline L-Threonine & 16 & $(31)$ & (11) & $\begin{array}{l}\text { All except 20I, 203,213,216,221, 225, 230, 238, 242, 244, 246, } \\
317,318,543,545,546\end{array}$ \\
\hline L-Tyrosine & $2 \mathrm{I}$ & (40) & (12) & $\begin{array}{l}\text { All except 102, 203,216, 217, 21 8, 222, 232, 238, 241, 307, 308, } \\
309,311,314,315,318,319,320,543,545,546\end{array}$ \\
\hline Putrescine & 63 & $(100)$ & $(8 I)$ & $202,204,211,215,228$ \\
\hline Spermine & 20 & (43) & (8) & $\begin{array}{l}\text { All except 102, 201, 222, 230, 238, 247,267,307,308, 309, 310, } \\
314,316,317,318,319,320,544\end{array}$ \\
\hline
\end{tabular}

Our study shows clearly the existence of two main clusters, $\mathrm{X}$ and $\mathrm{Y}$, for which we propose the rank of separate species. The differentiation of these two species is clear-cut if we consider the first seven characters of Table 7 , since the degree of strain conformity to their ideal phenotypes is satisfactory: $81 \%$ of X strains and $70 \%$ of $\mathrm{Y}$ strains are in agreement with all or all but one characters of the ideal phenotypes.

In differentiating between these two species, no significant diagnostic value was found in gas production from glycerol (which is redundant with gas production from glucose) or in butanediol dehydrogenase production. Hence we consider that $A$. hydrophila cannot be distinguished from $A$. punctata, and these two specific epithets must be considered as synonyms. This opinion is reinforced by the fact that the neotype strains of $A$. hydro- 
Table 7. Ideal phenotypes of classes $X$ and $Y$, and of biovars $X_{1}$ and $X_{2}$

The feature of the ideal phenotype is given, with (in parentheses) the percentage of strains having the same feature as the ideal phenotype.

Characters

Growth on L-histidine

Esculin hydrolysis

Growth on KCN medium

Growth on L-arabinose

Fermentation of salicin

Growth on L-arginine

Growth on salicin

Elastase production

Acetoin from glucose

Gas from glucose

$\mathrm{H}_{2} \mathrm{~S}$ in 'Gélose G.C.F.'
Class X (42 strains)

$$
\begin{aligned}
& +\quad(98) \\
& +\quad(100) \\
& +\quad(98) \\
& +\quad(93) \\
& +\quad(86) \\
& +\quad(74) \\
& +\quad(79)
\end{aligned}
$$

Class Y (26 strains)

$$
\begin{aligned}
& -(92) \\
& -\quad(81) \\
& =\quad(81) \\
& -\quad(81) \\
& -\quad(81) \\
& =\quad(92) \\
& -\quad(77)
\end{aligned}
$$

$$
\begin{array}{cc}
\text { Biovar } X_{1} & \text { Biovar } X_{2} \\
+(92) & -(100) \\
+(92) & -(97) \\
+(92) & -(86) \\
+(85) & -(93)
\end{array}
$$

+ , Character usually positive; - , character usually negative; \pm , non-significant frequency, the commonest result being shown in parentheses.

Table 8. DNA base compositions of some strains

$\begin{array}{cccc}\text { Strain } & \text { Class } & T_{\mathrm{m}}\left({ }^{\circ} \mathrm{C}\right) & \% \mathrm{GC} \\ 102 & \mathrm{X} & 79 \cdot 7 & 62 \cdot 9 \\ 218 & \mathrm{X} & 79 \cdot 3 & 6 \mathrm{I} \cdot 9 \\ 239 & \mathrm{X} & 79 \cdot 5 & 62 \cdot 5 \\ 246 & \mathrm{X} & 79 \cdot 7 & 62 \cdot 9 \\ 307 & \mathrm{X} & 79 \cdot 6 & 62 \cdot 7 \\ 208 & \mathrm{Y} & 78 \cdot 0 & 58 \cdot 8 \\ 209 & \mathrm{Y} & 78 \cdot 2 & 59 \cdot 2 \\ 245 & \mathrm{Y} & 78 \cdot 8 & 60 \cdot 7 \\ 262 & \mathrm{Y} & 74 \cdot 8 & 50 \cdot 9 \\ \text { Escherichia coli KI2 } & - & 74 \cdot 7 & 50 \cdot 7\end{array}$

Table 9. Summary of the most recent taxonomic studies on the hydrophila-punctata group

$\begin{array}{clc} & \text { Eddy (1960, 1962) } & \\ \text { Ewing } \text { et al. }(\mathrm{1} 96 \mathrm{I}) & \text { Leclerc (1962) } & \\ \text { One species } & \text { Merkel } \text { et al. }(1964) & \text { Schubert }(1969 a, b) \\ \text { A. hydrophila } & \text { Four species } & \text { Two species } \\ & \text { A. punctuta } & \text { A. hydrophila } \\ & \text { A. caviae } & \text { (three subspecies) } \\ & \text { A. dourgesi } & \text { A.punctata } \\ & \text { A.proteolytica } & \text { (two subspecies) }\end{array}$

phila subsp. hydrophila and of A. punctata subsp. punctata, and the type strains of A. hydrophila subsp. anaerogenes and of $A$. punctata subsp. caviae, are all found in the species $\mathrm{X}$.

According to Rule 42 of the International Code of Nomenclature of Bacteria (Lapage et al., I973), when two taxa of equal rank are united, 'the oldest legitimate name or epithet is retained'. Aeromonas hydrophila was first legitimately published as $B$. hydrophilus by Chester (I90I) and A. punctata by Snieszko in the 7th edition of Bergey's Manual of Determinative Bacteriology (1957) because the description of B. punctatus by Zimmerman (I 890) is unrecognizable (Ewing et al., 196I). Therefore, we propose to retain the name $A$. hydrophila for the species X, with the proposed neotype strain ATCC7966 as type strain (Opinion 
47 of the Code), and to give an amended definition of this species on the basis of the characters of cluster $\mathrm{X}$.

The species X, A. hydrophila, could be divided into two biovars. In the first one (subclass $\mathrm{X}_{1}$ ), most strains produce butanediol dehydrogenase ( $92 \%$ of the strains), gas and acetoin from glucose (see Table 7), and correspond to biotype I of $A$. hydrophila subsp. hydrophila as defined by Schubert in Bergey's Manual of Determinative Bacteriology (1974). The second biovar (subclass $\mathrm{X}_{2}$ ) does not produce gas or acetoin from glucose, gives variable results for the butanediol dehydrogenase test, and it corresponds to the anaerogenic strains of Aeromonas. Thus the subspecific epithet 'anaerogenes' could be retained for this biovar.

The reference strain of $A$. hydrophila subsp. proteolytica (strain 262) happens to be included in class $\mathrm{Y}$, but this strain differs from the others as follows: (i) phenotypically, in its sodium requirement - a fundamental physiological character reflecting a specific sodium requirement for a number of essential cellular processes (MacLeod, I968); (ii) genotypically, by the GC content of its DNA (50.9 mol \%) - a result agreeing with that of Baumann, Baumann \& Mandel (1971), but which falls outside the range of values for the GC content of the DNA quoted for the genus Aeromonas in Bergey's Manual of Determinative Bacteriology (1974). The peritrichous flagellation appearing when the strain is grown on solid medium (Baumann et al., I97I; McCarthy, 1975), the sodium requirement, the existence of species unique to the ocean (supported by an extensive study by Reichelt \& Baumann, 1974) and the GC ratio are convincing reasons for excluding $A$. hydrophila subsp. proteolytica from the genus Aeromonas. The taxonomic assignment of this bacterium requires the study of more strains, because only one strain is actually known (NCMBI $326=$ ATCCI 5338).

With exception of this strain, 262, all the others in class $\mathrm{Y}$ belong to the genus Aeromonas because they possess all the fundamental properties of the Aeromonas definition, and have an average GC value close to that of $A$. hydrophila (class X). But these strains do not correspond to any previously described species, and we propose that class $\mathrm{Y}$ should be designated $A$. sobria sp.nov. because of the comparatively small number of substrates that support growth. It can be distinguished from the first biovar of $A$. hydrophila by eight characters and from the second one by nine characters (Table 7 ).

The proposed emendation of the description of the type species $A$. hydrophila (syn. $A$. punctata) is as follows: It has the basic morphological and physiological characters of the genus Aeromonas given in Bergey's Manual of Determinative Bacteriology (1974); utilizes as sole source of carbon and energy, L-histidine, L-arabinose, L-arginine and salicin; hydrolyses esculin; grows on KCN medium; ferments salicin. This species can be divided into two biovars: (i) A. hydrophila biovar hydrophila which produces gas and acetoin from glucose, $\mathrm{H}_{2} \mathrm{~S}$ from cysteine, and elastase (reference strain: ATCC7966 $=$ NCTC8049 $=$ NCMB86 $=$ NCIB9240 = CDC-RH35); (ii) A. hydrophila biovar anaerogenes which does not produce gas and acetoin from glucose, $\mathrm{H}_{2} \mathrm{~S}$ from cysteine, and elastase (reference strain ATCCI 5468).

The formal description of $A$. sobria sp.nov. is as follows: possesses the basic morphological and physiological characters of the genus Aeromonas given in Bergey's Manual of Determinative Bacteriology (1974); does not utilize as sole source of carbon, L-histidine, Larabinose, L-arginine and salicin; does not grow on KCN medium, or hydrolyse esculin, or ferment salicin; produces gas from glucose and $\mathrm{H}_{2} \mathrm{~S}$ from cysteine; elastase negative. Type strain (holotype): strain $208=$ CIP7433.

This study was supported by a grant from I.N.S.E.R.M., France (A.T. No. 72.1.523.I4). We thank R. Y. Stanier for reading and criticizing the manuscript. 


\section{REFERENCES}

Baumann, P., BaumanN, L. \& Mandel, M. (1971). Taxonomy of marine bacteria: the genus Beneckea. Journal of Bacteriology 107, 268-294.

Bergey's Manual of Determinative Bacteriology, 7th edn (1957). Edited by R. S. Breed, E. G.D. Murray and N. R. Smith. London: Ballière, Tindall and Cox.

Bergey's Manual of Determinative Bacteriology, 8th edn (1974). Edited by R. E. Buchanan and N. E. Gibbons. Baltimore: Williams and Wilkins.

CHESTER, F. D. (I90I). In A Manual of Determinative Bacteriology, p. 234. New York: Macmillan.

Davis, B. R. \& EWING, W. H. (1964). Lipolytic, pectolytic and alginolytic activities of Enterobacteriaceae. Journal of Bacteriology 88, 16-19.

Delabre, M., Bianchi, A. \& VÉron, M. (1973). Étude critique de méthodes de taxonomie numérique. Application á une classification de bactéries aquicoles. Annales de Microbiologie 124A, 489-506.

DE LEY, J. (1970). Reexamination of the association between melting point, buoyant density, and chemical base composition of deoxyribonucleic acid. Journal of Bacteriology ror, 738-754.

EdDy, B. P. (1960). Cephalotrichous, fermentative, Gram-negative bacteria: the genus Aeromonas. Journal of Applied Bacteriology 23, 216-249.

EdDy, B. P. (1962). Further studies on Aeromonas. I. Additional strains and supplementary biochemical tests. Journal of Applied Bacteriology 25, 137-146.

Ewing, W. H., Hugh, R. \& Johnson, J. C. (1961). Studies on the Aeromonas group. Atlanta, Georgia, U.S.A.: U.S. Department of Health, Education and Welfare, Communicable Disease Center.

GyllenberG, H. (I965). A model for computer identificaton of micro-organisms. Journal of General Microbiology 39, 40I-405.

Kluyver, A. J. \& VAN Niel, C.B. (1936). Prospects for a natural system of classification of bacteria. Zentralblatt für Bakteriologie, Parasitenkunde, Infektionskrankheiten und Hygiene (Abteilung II) 94, 369-403.

Kulp, W. L. \& Borden, D. G. (1942). Further studies on Proteus hydrophilus, the etiological agent in 'red leg' disease of frogs. Journal of Bacteriology 44, 673-685.

Lapage, S. P., Clark, W. A., Lessel, E. F., Seeliger, H. P. R. \& Sneath, P. H. A. (1973). Proposed revision of the international code of nomenclature of bacteria. International Journal of Systematic Bacteriology 23, 83-108.

Leclerc, H. (1962). Diagnostic bactériologique des Aeromonas. Bulletin de l'Association des Diplômés de Microbiologie de la Faculté de Pharmacie de Nancy 88, I 2-20.

LySENKo, O. (I96I). Pseudomonas - an attempt at a general classification. Journal of General Microbiology 25, 379-408.

MCCARThY, D. H. (1975). Aeromonas proteolytica - a halophilic aeromonad? Canadian Journal of Microbiology 21, 902-904.

MACLEOD, R. A. (1968). On the role of inorganic ions in the physiology of marine bacteria. Advances in the Microbiology of the Sea $\mathbf{1}, 95-126$.

MARMur, J. \& Doty, P. (1962). Determination of base composition of deoxyribonucleic acid from its thermal denaturation temperature. Journal of Molecular Biology 5, 109-1 18.

Merkel, J. R., Traganza, E. D., Mukherjee, B. B., Griffin, T. B. \& Prescott, J. M. (I964). Proteolytic activity and general characteristics of a marine bacterium, Aeromonas proteolytica sp.n. Journal of Bacteriology 73, 247-252.

Pivnick, H. \& Sabina, L. R. (I957). Studies of Aeromonas formicans Crawford comb.nov. from soluble oil emulsions. Journal of Bacteriology 73, 247-252.

Popoff, M. (1969). Étude sur les Aeromonas salmonicida. I. Caractères biochimiques et antigéniques. Recherches vétérinaires $3,49-57$.

ReICHELT, J. L. \& BAUMANN, P. (I974). Effect of sodium chloride on growth of heterotrophic marine bacteria. Archives of Microbiology 97, 329-345.

Richard, C., Giammanco, G. \& Popoff, M. (1974). Vibrio parahaemolyticus: isolement et diagnostic bactériologique. Annales de Biologie Clinique 32, 33-40.

SANARELl, G. (189I). Ueber einen neuen Mikroorganismus des Wassers, welcher für Thiere mit veraenderlicher und konstanter Temperatur pathogen ist. Zentralblatt für Bakteriologie, Parasitenkunde, Infektionskrankheiten und Hygiene 9, 193-228.

SCHÄPERClaus, W. (I930). Pseudomonas punctata als Krankheitserreger bei Fischen. Zeitung für Fischerei $28,289-370$.

SChARMANN, W. (1972). Vorkommen von Elastase bei Pseudomonas und Aeromonas. Zentralblatt für Bakteriologie, Parasitenkunde, Infektionskrankheiten und Hygiene. (Abteilung I) A220, 435-442.

Scherago, M. (1936). An epizootic septicemia of young guinea pigs caused by Pseudomonas caviae n.sp. Journal of Bacteriology 31, 83-85.

SCHUBERT, R. H. W. (1967a). The taxonomy and nomenclature of the genus Aeromonas Kluyver and van Niel 1936. I. Suggestions on the taxonomy and nomenclature of the aerogenic Aeromonas species. International Journal of Systematic Bacteriology 17, 23-37. 
Schubert, R. H. W. $(1967 b)$. The taxonomy and nomenclature of the genus Aeromonas Kluyver and van Niel 1936. II. Suggestions on the taxonomy and nomenclature of the anaerogenic aeromonads. International Journal of Systematic Bacteriology 17, 273-279.

SCHUBert, R. H. W. (I968). The taxonomy and nomenclature of the genus Aeromonas Kluyver and van Niel 1936. III. Suggestions on the definition of the genus Aeromonas Kluyver and van Niel 1936. International Journal of Systematic Bacteriology 18, $1-7$.

SCHuberT, R. H.W. (1969a). Infrasubspecific taxonomy of Aeromonas hydrophila (Chester 190I) Stanier 1943. Zentralblat fïr Bakteriologie, Parasitenkunde, Infektionskrankheiten und Hygiene (Abteilung I) 2II, 406-408.

SCHUBERT, R. H.W. (1969b). Aeromonas hydrophila subsp. proteolytica (Merkel et al., 1964) comb.nov. Zentralblatt für Bakteriologie, Parasitenkunde, Infektionskrankheiten und Hygiene (Abteilung I) 2II, 409-4r2.

SCHUBERT, R. H. W. \& KeXel, G. (1964). Der Ausfall der Butanedioldeshydrogenase-Reaktion bei einigen Pseudomonadacen und Vibrionen. Zentralblatt für Bakteriologie, Parasitenkunde, Infektionskrankheiten und Hygiene (Abteilung I) r94, I 30-1 32.

Sebald, M. \& Véron, M. (1963). Teneur en bases de l'ADN et classification des vibrions. Annales de l'Institut Pasteur ro5, 897-910.

Silvestri, L., Turri, M., Hill, L. R. \& Gilardi, E. (1962). A quantitative approach to the systematics of Actinomycetes based on overall similarity. Symposia of the Society for General Microbiology 12, 333-360.

Sмiтн, I. W. (1963). The classification of 'Bacterium salmonicida'. Journal of General Microbiology 33 , 263-274.

Sokal, R. R. \& Sneath, P. H. A. (1963). Principles of numerical taxonomy. San Francisco and London: W. H. Freeman.

Speck, M. L. \& StaRK, C. N. (1942). The gas ratio and some correlated distinguishing properties of bacteria of the genus Proteus. Journal of Bacteriology 44, 687-70 I.

Stanier, R. Y., Palleroni, N. J. \& Doudoroff, N. (1966). The aerobic Pseudomonads: a taxonomic study. Journal of General Microbiology 43, I 59-27I.

VÉRON, M. (1966). Taxonomie des vibrions et de certaines bactéries comparables. II. Corrélation entre les similitudes phénétiques et la composition en base de l'ADN. Annales de l'Institut Pasteur III, 67 I-709.

Véron, M. (1974). Sur un critére de calcul du meilleur niveau de coupure d'un dendrogramme de classification hiérarchique. Annales de Microbiologie 125B, 29-44.

Véron, M. (1975). Nutrition et taxonomie des Enterobacteriaceae et bactéries voisines. I. Méthode d'étude des auxanogrammes. Annales de Microbiologie 126A, 267-274.

VÉRON, M. \& GASSER, F. (1963). Sur la détection de l'hydrogène sulfuré produit par certaines entérobactériacées dans les milieux dits de diagnostic rapide. Annales de l'Institut Pasteur 105, 524-534.

Zimmerman, O. E. R. (1890). Die Bakterien unserer Trink- und Nutz-wässer insbesondere des Wassers der Chemnitzer Wasserleitung. 1. Reihe. Elfter Bericht der Naturwissenschaftlichen Gessellschaft $z u$ Chemnitz $x, 38-39$. 